\title{
ALÉM DA RACIONALIDADE: O ESTUDO DAS EMOÇÕES COMO PRÁTICAS POLÍTICAS*
}

\author{
María Inés Fernández Álvarez
}

\section{Introdução}

Foi no final de abril de 2002, numa sala de aula da Faculdade de Filosofia e Letras da Universidade de Buenos Aires, que ouvi Julia ${ }^{1}$ falar pela primeira vez. Ela era operária da confecção, e eu teria a oportunidade de conhecê-la pessoalmente algumas semanas depois. Com o seu guarda-pó azul-claro desabotoado, pediu permissão para falar e se dispôs a relatar "a história da sua fábrica". Acompanhavam-na dois jovens rapazes, que era possível adivinhar serem militantes universitários. Ambos levavam uma caixa de papelão com uma inscrição dizendo "fundo de greve". Durante os 10 minutos em que Julia usou da palavra, narrou brevemente uma história que depois eu escutaria sucessivamente em discussões públicas, encontros com organizações sociais e entrevistas com jornalistas ou estudantes universitários. O relato começava no dia 18 de dezembro de 2001, quando um grupo de operárias e operários da confecção, no qual ela estava incluída, ocupara a fábrica onde trabalhava há mais de dez anos. "Os donos foram embora e não voltaram mais. Na última sexta-feira, recebemos um vale de 5 pesos e não podíamos nem voltar para as nossas casas. Ficamos, para proteger a nossa fonte de trabalho, que é a única coisa que temos". Antes de se despedir, Julia nos convidou a colaborar com o "fundo de greve" e a nos aproximarmos da fábrica para apoiar a medida.

A história narrada por Julia tivera lugar na véspera das "jornadas de 19 e 20". No começo de dezembro daquele ano, no contexto de uma profunda recessão econômica, o ministro da Economia, Domingo Cavallo, anunciou o corralito, que limitava a possibilidade de se retirar dinheiro dos bancos. ${ }^{2}$ Nos dias seguintes, foram realizados panelaços - a saída às ruas de "vizinhos", batendo panelas — na cidade de Buenos Aires, e houve saques a supermercados em diferentes regiões do país. No dia 19 de dezembro, os 
saques se multiplicaram e foram reprimidos, provocando a morte de seis pessoas e mais de cem feridos. Às $22 \mathrm{~h}$ o presidente da nação, Fernando de la Rúa, decretou o estado de sítio. Enquanto a medida era anunciada em rede nacional, começaram a se multiplicar os panelaços e as manifestações em diversas regiões do país, uma delas dirigida à Casa de Governo. Com o slogan "fora todos", as/os manifestantes pediam a renúncia das autoridades. Por volta de 1 hora da madrugada do dia 20 de dezembro, o ministro da Economia renunciou ao seu cargo. Não obstante, algumas pessoas permaneceram em frente à Casa de Governo, multiplicando-se o número de manifestantes nas horas seguintes. Exigiam a renúncia ${ }^{3}$ do presidente da nação e de todo o gabinete. No meio da manhã da quinta-feira, dia 20, começou uma forte repressão, que se acirrou nas primeiras horas da tarde, provocando detenções, feridos e mais de 30 mortes em todo o país. Logo depois das 19h, o presidente anunciou a sua renúncia. Piquetes na rua, mobilizações, assembleias de bairro e outras ações de protesto foram parte do cenário cotidiano daqueles que moravam na Argentina naquele momento. Como parte desse cenário, entre dezembro de 2001 e abril de 2002, o caso que Julia narrava ganhou notoriedade pública e outras fábricas em situações semelhantes foram ocupadas por suas/seus trabalhadoras/es. Mais tarde seriam conhecidas como "recuperadas". ${ }^{4}$

Embora tivesse informação sobre esses processos por meio da mídia, era a primeira vez que escutava o relato da boca de uma de suas protagonistas. Lembro que a força das palavras de Julia chegou a me comover. Naquele momento, estava finalizando a redação de um projeto de pesquisa para me candidatar ao doutorado na Universidade de Buenos Aires, em que propunha desenvolver um estudo etnográfico sobre as consequências da "Reforma Trabalhista" dos anos 90 para as pessoas que faziam parte do reduzido "mercado de trabalho". Na reconstrução que Julia fazia da ocupação, o propósito do meu estudo ficava mais como pano de fundo, parte de uma história passada que, ainda assim, dava força às práticas que descrevia. Acima de tudo, a história que Julia contava produzia em mim uma espécie de admiração em relação àquilo que essas pessoas tinham se animado a fazer. Essa sensação me orientou a redefinir a pesquisa com a ideia de desenvolver um estudo etnográfico sobre o processo que descrevia. Poucos dias depois eu ingressava na fábrica pela primeira vez.

Nas semanas seguintes, visitei aquele espaço regularmente. Durante essas visitas escutei as/os companheiras/os de Julia reproduzindo aquele relato diante de uma inumerável quantidade de pessoas que, como eu, se aproximavam diariamente para conhecê-los, oferecer-lhes apoio ou estudálos. ${ }^{5}$ Como resultado de uma combinação de elementos que incluíam a data 
da recuperação, o componente principalmente de mulheres, o processo de construção das demandas e as vinculações que estabeleceram com partidos de esquerda, este caso foi considerado um dos mais politizados, tornando-se um "exemplo de luta". Nesse sentido, meu estudo seguia um 'objeto quente', um caso que tinha chamado a atenção pública, ganhando adeptos e detratores, a respeito do qual se opinava, fosse para exaltar o heroísmo de seus protagonistas ou para questionar a radicalidade das suas demandas.

Durante esse tempo fui entendendo que, nesse contexto, contar "sua história" era parte de uma atividade central entre as práticas que se desenrolavam a partir da ocupação. A repetição de certos eventos e das formas de narrá-los tinha conformado uma espécie de história oficial da ocupação. Essa narrativa expunha uma série de argumentos que situavam a ação desencadeada como resultado do não cumprimento, por parte dos empregadores, do pagamento do salário, e o abandono da empresa. ${ }^{6}$ Diante disso, sinalizavam que se fizera necessário "proteger a fonte de trabalho" como única forma de manter um trabalho digno. Nesse relato público recuperavase uma terminologia que enquadrava as práticas (próprias e alheias) numa lógica de legitimidade/ilegitimidade, destacando-se o uso de categorias técnico-jurídicas como "esvaziamento", 7 "direito ao trabalho" ou concurso preventivo. ${ }^{8}$ À medida que a minha presença na fábrica foi se tornando cotidiana, pude observar que, em situações de maior intimidade, a reconstrução deste processo adquiria outro registro no qual as emoções, as sensações e os sentimentos ganhavam maior centralidade. Termos como raiva, esperança ou medo eram recorrentes nessas narrativas, que reconstruíam cenas de desespero e angústia diante da incerteza quanto ao futuro da empresa. Se na apresentação da história oficial o apelo ao registro emotivo aparecia subordinado à legitimação das ações desenvolvidas, nos relatos mais íntimos esses termos eram expressão direta de um padecimento encarnado, vivido cotidianamente por essas pessoas e suas famílias.

Pesquisas recentes chamaram a atenção sobre a necessidade de reconsiderar o lugar das emoções no protesto e na mobilização social (Jasper \& Goodwin 2006; Goodwin, Jasper \& Polletta 2001; Polletta 1998). Afirmando seu caráter social e cognitivo, as emoções foram consideradas por estes enfoques como dimensões explicativas das motivações individuais para a ação coletiva. Em particular, alguns autores (Calhoun 2001) destacaram que o estudo das emoções nas ciências sociais esteve ligado a falsos dualismos, colocando-as no polo oposto ao da ação racional. A dicotomia racional-irracional ganhou centralidade nestas argumentações, na medida em que a teoria da ação coletiva na qual se inscrevem foi desenvolvida em diálogo com as visões irracionais do comportamento 
coletivo. ${ }^{9}$ Em contraposição, propostas recentes expressaram uma permanente preocupação em recolocar as emoções no lugar das ações racionais, produzindo uma espécie de racionalização das emoções. Pensadas em termos de causas motivacionais, "o emocional" - assim como "o cultural" ou "o simbólico" - ficou reduzido a fatores que explicaram o surgimento da mobilização ou o protesto. ${ }^{10}$

Desde os anos 1980, a antropologia desenvolveu uma linha de trabalho cujos aportes têm sido substantivos para o estudo das emoções na vida social e nas práticas políticas (Lutz 1986; Abu-Lughod 1985; Lutz \& White 1986; Abu-Lughod \& Lutz 1990; Lyon 1995; Rosaldo 1984). Destacando o seu caráter cultural, esta perspectiva mostrou que o olhar eurocêntrico, a partir do qual foram tradicionalmente abordadas as emoções, situou-as no lugar da irracionalidade, da subjetividade ou no espaço privado do interesse individual. ${ }^{11}$ Através de outros enfoques, alguns trabalhos pioneiros da disciplina contribuíram para complexificar o estudo dos movimentos sociais, mostrando o peso das emoções no desenvolvimento de práticas políticas (Worsley 1980). A meu ver, o estudo de P. Worsley aporta elementos substantivos, na medida em que desloca o eixo de debate sobre o caráter (ir)racional da ação. Ao destacar a articulação entre o desejo ou a frustração dos "povos colonizados" com os processos políticos mais amplos, afirma o caráter político dos movimentos milenaristas em contraposição à consideração destes últimos como fenômenos patológicos. A expressão "histéricas" em jogo nos movimentos que analisa é entendida pelo autor como uma manifestação das emoções geradas pela tensão da "situação colonial" que as pessoas desenvolvem para além de sua vontade e intenção.

Ainda que partindo de enfoques conceituais diferentes, considero que estes estudos podem se articular numa linha de indagação sobre o potencial das emoções na pesquisa dos processos políticos. A meu ver, esta consideração abre um caminho que permite nos deslocarmos de um debate fundamentado em termos de racionalidade-irracionalidade para a introdução de uma compreensão das práticas (políticas) a partir da experiência encarnada (Csordas 1994). Com este fim, retomo resultados de um estudo etnográfico sobre recuperações de fábricas na cidade de Buenos Aires que desenvolvi entre 2002 e $2005 .{ }^{12}$ Neste artigo reconstruo as narrativas das operárias e dos operários sobre o início da recuperação $0^{13}$ em cuja base sustento que a entrada em jogo de emoções e sentimentos permitiu articular a experiência e definir as primeiras reivindicações. A conformação das demandas, por sua vez, implicou um processo de objetivação dessa experiência (a conformação de uma história oficial) e, ao mesmo tempo, de exposição (pública) de determinadas emoções e sentimentos. 


\section{"E fomos ficando...": a antessala da ocupação}

No dia 18 de dezembro de 2001, Margarita levantou minutos antes das 4 da manhã, preparou um mate que bebeu rapidamente enquanto preparava sua bolsa, e tomou o rumo de La Celeste, onde trabalhava como costureira desde o início dos anos 90. Levava com ela umas poucas moedas, suficientes apenas para chegar à fábrica, as últimas que restavam do vale de 5 pesos que tinha recebido na sexta-feira anterior. Às 6 da manhã ingressou na fábrica. Trocou sua camisa florida pelo guarda-pó azul-claro e sentou-se em seu posto de trabalho. A manhã transcorreu lentamente. O ritmo acelerado das máquinas, ao qual estava acostumada, adquirira outra cadência. Nos dias anteriores, em reação à diminuição dos vales, tinha começado, junto com suas/seus companheiras/os, a diminuir a produção. A partir de então, uma sensação de mal-estar percorria o terceiro andar, onde funcionava o setor "bolsa", no qual ela trabalhava desde seu ingresso na fábrica.

Alguns dias antes, no ponto do ônibus, soubera por uma de suas colegas que um grupo delas, preocupadas com a situação que parecia não ter saída na fábrica, tinha contatado um advogado. Seguindo o conselho do especialista, tinham enviado um telegrama mediante o qual se consideravam despedidas, com o objetivo de receber algum dia o seguro-desemprego. ${ }^{14} \mathrm{O}$ relato da sua colega aumentava seu temor de perder o trabalho, uma inquietação crescente que tinha se exacerbado ainda mais quando fora notificada de que as férias diferentemente do que acontecera em outros anos - tinham sido estabelecidas para todo o pessoal ao mesmo tempo. Este cenário lembrava-lhe o dia em que, em meados de 2000, depois de uma suspensão de duas semanas, chegara à fábrica e encontrara-a com uma faixa de interdição. ${ }^{15}$

Os acontecimentos aceleraram-se e, no fim do dia, estava numa assembleia na qual discutia com suas/seus companheiras/os a possibilidade de permanecer na fábrica. Numa entrevista que realizei com ela meses depois no local, quando a "sua fábrica" tinha se convertido numa das primeiras recuperadas da cidade de Buenos Aires, Margarita relatou da seguinte maneira a sua lembrança desse dia:

O último vale foi de 5 pesos, depois eles foram embora [em referência aos donos da empresa]. Eles foram, e as pessoas que não tinham dinheiro para viajar foram ficando... Porque já vínhamos de uma semana... Era uma terça-feira... Lembro que na sexta-feira fomos embora todos mal, todos assim... Porque tinham nos dado 5 pesos, na segunda-feira apareceram com 5 pesos, e a gente foi embora, quem pôde ir, foi. Na terça viemos cedo... Normal, para trabalhar, com a esperança de que Ricardo [o chefe de pessoal] nos daria os vales às 
10 da manhã. Mas não. Não apareceu às 10 , nem às 11 , nem às 12 . Depois falou por telefone que não conseguiu o dinheiro. E, bem, nós ficamos com isso, com a esperança de que ele estava por lá apanhando o dinheiro [...] Eu, pelo menos, nem aí pensei que ia chegar até agora... Eu disse, não, é capaz de que amanhã venham, tragam o nosso vale e vamos embora. Ou nesta mesma noite, ficamos, ou eles vêm às 7 ou 8 , voltam e trazem os nossos vales. Eram 7, 8, 11, 12 e nada (Margarita, 58 anos, há 13 anos na empresa).

Sentada em sua máquina, Margarita relatava o modo como, pouco a pouco, foram ficando na fábrica. Descrevia o mal-estar, que compartilhava com os colegas, pelo atraso no pagamento dos vales acumulados, contrapondo o abandono dos donos à sua permanência no lugar. Nessa descrição, destacava a sensação de esperança com que chegou nesse dia e aquela com que foi ficando enquanto aguardava o pagamento do seu vale. Nesse relato, mais que uma ação que irrompeu na sua vida, o fato de permanecer na fábrica aparece como uma consequência quase 'natural', inevitável, inscrita na sua cotidianidade. Margarita expressava ao mesmo tempo a vivência de uma relação debilitada (em relação aos donos) e o desejo de uma resolução não alcançada. Em relação a este último, nas minhas primeiras visitas à fábrica, uma das questões que mais me surpreenderam em minhas trocas com as/os operárias/os foi a expressão de desejo (ainda que apresentado como impossível) de que os donos voltassem a se encarregar da empresa, mantendo-os como empregados e pagando suas dívidas. Esta questão chamava a minha atenção não porque me parecesse incompreensível, mas porque se contrapunha à imagem pública que se projetava delas/es. Sem dúvida, este ideal não era assumido pelo conjunto de trabalhadoras/es de maneira homogênea. Não obstante, constituía uma referência frequente para muitos/as. Esta expressão se completava com o relato de anedotas de momentos compartilhados com os donos ou parte dos quadros superiores, em que estes se mostravam como pessoas próximas e com sentimentos afáveis em relação a elas/es. Um relato marcado por expressões afetivas, seja de proximidade ou distância.

Assim como Margarita, Beatriz levava "toda uma vida dedicada à costura" no dia em que suas/seus companheiras/os informaram que iam descer até o primeiro andar - onde ficavam os escritórios dos donos e dos quadros superiores - para exigir o pagamento dos salários atrasados. Seu marido vinha insistindo para que deixasse de trabalhar "também, não dava nem para viajar", mas ela não queria "entregar sua indenização de mão beijada", seus anos "sentada na máquina". Uma tarde, enquanto cumpria a sua vigilância, ${ }^{16}$ entrevistei-a pela primeira vez. Beatriz tinha então 49 anos 
e morava em Villa Tesei com seu companheiro e seus quatro filhos. Fazia 28 que trabalhava na indústria de vestuário. Ter conseguido manter-se tanto tempo no mesmo ofício, sempre em "fábricas grandes", de renome, era algo que a orgulhava e que mencionava frequentemente. Definia-se como "uma mulher de muita fé" e no seu relato evocava Deus repetidas vezes, sobretudo quando lembrava os momentos difíceis pelos quais tinha passado. O início da ocupação era um deles, como testemunhava a medalhinha da Virgem que, presa à aba do seu avental, acompanhava-a desde então. Numa tarde de novembro de 2002 - quase um ano depois do início da ocupação propus a ela fazer uma entrevista "sobre a sua vida", quando finalizasse a "jornada de trabalho". Falamos por um longo tempo, durante o qual ela foi me contando parte da sua história, até que fez referência ao dia em que "ficaram", segundo suas palavras, "por raiva":

B: Depois começou tudo a vir abaixo (silêncio).

MI: Você estava no dia em que ficaram aqui?

B: Sim.

MI: Quer me contar como foi esse dia pra você?

B: Olha, vou te dizer como ficamos, nós ficamos... Eu acho que mais por raiva, mais por raiva não porque a gente pensava em ficar, foi pela resposta de $\mathrm{X}$ [nome de um dos donos], porque já nesse momento a menina tinha descido para falar com ele, com a senhora que estava nesse momento e toda a gente do escritório. Eu acho que não fomos embora por raiva, que ficamos; raiva no sentido de tudo o que a gente ia acumulando do dinheiro que estávamos levando e com muito trabalho e muita exigência, porque eles pediam, por exemplo, que entregássemos o trabalho, que terminássemos, exigiam muita produção, porque tinha muito trabalho, isso é o que a gente não compreende, para onde ia e por que não entrava o dinheiro, com tanto trabalho; porque posso te dizer, bom, sim, teria razão se não produzíssemos, se não tivesse trabalho aqui dentro, aí sim, a coisa ia mal, mas tinha muito trabalho, e como exigiam o trabalho e nos davam o que nos davam de vale... (Beatriz, 49 anos, operária qualificada, há 12 anos na empresa).

Respondendo à minha pergunta sobre o dia da ocupação, Beatriz evocava a sensação de raiva que lhe permitiu ficar, ou mais exatamente "não ir embora", como uma ação "não pensada". Essa raiva fundava-se no inexplicável comportamento dos "donos" que, embora "exigissem produção", não cumpriam com o pagamento dos salários. Fazendo referência à contraposição entre exigência e não cumprimento, a raiva era reforçada na falta de reconhecimento do seu trabalho. Partindo deste sentimento, rememorava a sensação de traição e abuso que tinha desencadeado a permanência na 
fábrica, não como uma ação premeditada, mas melhor dizendo, como uma consequência inevitável. Assim, sua descrição inscrevia esse ato no âmbito da sua relação com "os donos", como uma resposta às suas ações.

Com base nesta reconstrução, observamos que, nas descrições de Margarita e Beatriz sobre o começo da ocupação, o registro emotivo, moldado em referências às sensações de medo, esperança ou raiva, ganhou centralidade. Seguindo este argumento, as emoções que elas evocam poderiam constituir a base para explicar o envolvimento de ambas na ocupação. Raiva ou esperança seriam, assim, fatores para entender por que Margarita e Beatriz decidiram estrategicamente - ficar no dia 18 de dezembro ocupando a fábrica.

O problema desta argumentação reside, a meu ver, em formular uma pergunta que elas não se fizeram. Quando voltamos a esses relatos, observamos que a permanência na fábrica é descrita principalmente como uma ação não pensada. Para usar suas palavras, o fato de não ir embora aparece como uma consequência inevitável e quase 'natural' do curso dos acontecimentos. Uma ação que vai além da vontade e da intenção, retomando a discussão proposta por Worsley (1980), na qual emoções e sentimentos articulam uma experiência cotidiana de frustração pelos atrasos nos pagamentos e o acúmulo de dívidas salariais que se combinava com exigências de produtividade. A ocupação da fábrica aparece, a partir desta ótica, como uma ação mais mediada pelas relações - entre eles/as e com os donos - do que como resultado de um cálculo de custo-benefício, tão próxima ao caráter das ideias como ao dos afetos e sentimentos.

Em relação a este ponto, algumas/alguns autoras/es (Lyon 1995; Reedy 1997) refletiram sobre as implicações dos enfoques construtivistas no estudo das emoções, enfatizando a necessidade de deslocar o olhar para incluir a consideração dos afetos. Seguindo o seu argumento, isto supõe uma compreensão das emoções não como estados internos cujas expressões devem ser estudadas, mas sim como um fenômeno social que é sempre relativo a outro. Recuperar esta consideração permite recolocar a descrição que estas mulheres fazem no registro que elas trasmitem desse momento, deslocando o interrogante pelas motivações da ação - e consequentemente a sua (ir)racionalidade - para observar a trama de relações na qual foi possível levar adiante a recuperação, como veremos a seguir.

No $5^{\circ}$ andar da fábrica funcionava a seção de montagem de calça, na qual trabalhavam Julia, Pedro e Eduardo. Pedro morava em Buenos Aires desde o começo dos anos 90, quando saíra de Oruro (Bolívia) em busca de trabalho. Julia e Eduardo tampouco eram portenhos. Ela saiu de Salta, província do norte da Argentina, seguindo o pai dos seus filhos, que viera do Peru "por problemas econômicos". Um domingo de manhã, em meados de 
2003, Julia me recebeu na sua casa, um apartamento localizado no bairro de Paternal, o qual tinha conseguido junto com outras famílias, depois de um longo processo de ocupação e luta pela moradia. Residia ali com seus três filhos, seu parceiro e sua cunhada, que "a ajudava com as crianças". Durante um mate foi me contando sobre sua chegada a Buenos Aires, onde tinha iniciado a luta para conseguir sua moradia a partir do contato com uma organização à qual se vinculou pouco tempo depois de chegar à capital, e a forma como essa luta se encadeou com a briga pelo emprego. Enquanto seus filhos subiam e desciam de seu colo, Julia reconstruía aqueles tempos da seguinte maneira:

$\mathrm{J}$ : Nesse momento em que sai esta casa, quando conseguimos esta moradia, muito feliz eu dizia, "bom, agora sim, temos alguma coisa nossa", pagar a prestação... Ali edificamos aos pouquinhos alguma coisa. Passam poucos meses, três meses tinha... Nem seis meses estive morando aqui com o que eu ganhava da fábrica, tentando juntar e ver, viu, como sustentava aqui, porque a prestação da casa é 260 mais ou menos... E vem acontecer isso [referindo-se à fábrica]. Uma depressão me pegou de jeito! e eu disse, "Ih, agora o que é que eu faço?", porque eu não queria deixar de pagar a prestação, porque como era que tinha lutado tanto por alguma coisa, um crédito, alguma coisa, e agora não poder pagar...

MI: Agora, quando foi que despejaram vocês da fábrica?

J: Não. Isso foi quando a... Foi embora... No dia 18 de dezembro de 2001. Isso acho que foi uma das iniciativas, foi... Foi a raiva que me permitiu ficar na fábrica. Para alguns colegas era ficar, para mim foi a tomada da fábrica. Porque sentamos com alguns colegas para conversar e eu contei a eles, disse a eles, "não posso pagar a minha casa, estou mal, é com um banco, viu?". Estava preocupada demais, sentava ali e chorava, e o meu marido estava, meu cunhado, e eu digo a eles, "não tenho nada para...". Meu marido estava sem trabalho... E eu digo, "não sei como fazer para viver esta semana". Pelo que vinham nos pagando, o último já eram 5 pesos que vinham dando para a gente. Depois a gente se juntava com alguns companheiros e, sabe, que coisa boa! Então a gente se juntou com os companheiros. Falamos perto da esquina e eu digo, "O que vamos fazer?", e já quando nos deram os dois pesos, bom, aí já chega... Então eu digo chega! Não, isso daqui não dá mais para recuperar, eles [os donos da empresa] querem tirar as coisas dali e ir embora (Julia, 33 anos, há sete anos na empresa).

A sensação de raiva que Beatriz e Margarita tinham evocado reapareceu também no relato de Julia. Mas, diferentemente de suas companheiras, ela falava da "tomada da fábrica", expressão que preferia à de permanecer, ins- 
crevendo essa ação numa "vida de luta" — primeiro pela habitação e depois pelo emprego. Como parte deste relato, Julia evocava o sofrimento diante da impossibilidade de continuar mantendo os seus, o desespero e o temor diante da possibilidade de perder tudo. Uma série de sensações que ressaltou, de forma enfática, em termos como depressão. Nesta linha, parece interessante a maneira como ela fala dessa raiva "que permitiu que ficasse", habilitando-a a ocupar a fábrica, a raiva como um correlato da sensação de injustiça. Ao mesmo tempo, destaca a preocupação por se organizar quando sentia que a fábrica ia fechar. Nesse percurso, descreve os encontros com suas/seus companheiras/os para quem transmitia a necessidade de "fazer alguma coisa" momentos em que mostrava a sua preocupação, expunha a sua intimidade e compartilhava a sua angústia, convidando-as/os a se juntarem.

Alguns meses antes da ocupação, o $5^{\circ}$ andar tinha ficado sem delegados, e Julia tinha insistido para que Pedro assumisse este papel. Nesse ano, ela e algumas de suas companheiras vinham "ganhando terreno" de Antonia, a encarregada, comemorando os aniversários durante o horário de almoço. Mas nos últimos tempos uma companheira que trabalhava na limpeza tinha transmitido a elas a sua preocupação pelas "movimentações estranhas" que vinha observando no primeiro andar, onde funcionava a administração e os escritórios de direção. "Os donos", segundo dizia, "estavam levando as coisas embora". Estes movimentos atípicos, somados ao atraso nos pagamentos semanais e ao anúncio das férias coletivas em janeiro, inquietavam tanto Julia, Pedro e Eduardo como alguns de seus colegas de outros andares, que começaram a se reunir ao sair da fábrica.

A moça da limpeza tinha nos contado que estavam levando as coisas embora, a geladeira, coisas pessoais, eles iam levando. Por exemplo, a geladeira da dona, não sei quais outras coisas que eles tinham levado, e a gente dizia, "Não! Eles estão quase indo embora!", e ainda por cima já faltava uma semana para todos saírem de férias. Mas não! Nós dizíamos não! Eles estão quase indo embora! E no desespero nos juntamos e dissemos, "Não. Temos que ficar. Temos que tomá-la". "Bem, mas vamos falar, vamos falar com os companheiros, com os que quiserem ficar. Eu acho que tem muitos que têm raiva, e também não importa, nós vamos ficar". Como os donos iam embora... E, bom, e a gente sempre tinha dito, "Vamos ficar para pedir os vales até que tragam o dinheiro. Ficamos para pedir os vales, colocamos cadeado e ficamos trancados ali". Eu tinha pedido ajuda aos meus vizinhos. Os mesmos que tinham lutado pela moradia. Quem sabe eles não podiam ficar por perto, se acontecesse alguma coisa conosco. Eu tinha medo da polícia, vai saber... Bom, chega esse dia, para isso eu falei com muitas companheiras: "Olhem, meninas, nós vamos 
ficar. Estamos decididos a ficar, sim ou sim. Mesmo que venham e nos deem 20 pesos, nós vamos ficar". Porque não eram 20 pesos o que estava em jogo (Julia, 33 anos, há sete anos na empresa).

Assim como nos trechos anteriores, nesta narrativa de Julia sobre os momentos que antecederam a ocupação, sentimentos como desespero ou angústia ganharam centralidade. Mas, no seu caso, esses sentimentos compartilhados com suas/seus companheiras/os e que, segundo ela, as/os tomavam eram um primeiro passo para se unirem numa ação conjunta. A princípio, juntar-se era tornar comuns as sensações. Depois, implicava organizar-se. Julia afirmava, "no desespero, nos juntamos". E segundos depois mencionava que nessas conversas com suas/seus companheiras/os de andar, nas quais transmitia seu desespero, foram pensando que esta sensação podia ser vivida também por outras/os que, como elas/es, tinham raiva. Desta forma, era possível ficar, tomar a fábrica. Neste caso, as emoções não aparecem como o correlato de uma ação que naturalmente se inscreve nos acontecimentos do dia. Ocupar a fábrica requeria para Julia organizarse, exigia algo mais que compartilhar o desespero. Para isso, como tinha aprendido em experiências anteriores, era preciso transformar as emoções compartilhadas em organização.

Quando observamos os relatos feitos por Margarita, Beatriz e Julia sobre a antessala da recuperação de sua fábrica, vemos que a consciência e a (falta de) vontade entremeavam-se: a ocupação para umas/uns, a permanência para outras/os podem ser ao mesmo tempo uma concepção de vida aprendida na luta e sensações de raiva que se sentem no estômago. A literatura sobre ação coletiva ou movimentos sociais tende a provocar um olhar dicotômico que contrapõe a ação racional estratégica à ação direta e "espasmódica" das "multidões". O problema dessa dicotomia, julgo eu, é que ela associa a ação racional a uma ação voluntária, consciente, planejada e, em oposição a ela, as expressões não conscientes e/ou involuntárias ficam situadas no domínio da irracionalidade. Ou, mais arriscado ainda, haveria pessoas que atuam de forma racional e outras que seguem pulsões naturais ou a vontade de outros. Neste ponto, acredito, revela-se fértil avançar numa linha de análise para o estudo dos processos políticos que contemple as emoções como expressão do "corpo como corpo" (Lyon 1995). Nos termos desta autora, trata-se de sair de uma conceitualização do corpo como representação em que as emoções provêm de pensamentos corporificados para um olhar do "corpo como mente", um reconhecimento da corporalidade da emoção que inclui o entendimento das relações sociais como necessariamente corporais (Lyon 1995:256). Seguindo esta abordagem, entendo que 
é possível contemplar o peso que a partilha de sentimentos e emoções teve na articulação de uma experiência comum de sofrimento e injustiça, mesmo quando esta podia ser significada de maneira diversa segundo variáveis relativas às trajetórias e às condições de vida, permitindo assim definir as primeiras reivindicações.

\section{Do "vale digno" à "defesa do trabalho": a construção de uma demanda}

Às 11 da manhã de terça-feira, operárias e operários de diferentes setores desceram até o primeiro andar para exigir o pagamento de um vale digno. Inés tinha naquele momento 39 anos e trabalhava na firma desde meados dos anos 90. Tinha chegado à fábrica pelas mãos de sua cunhada, também empregada da empresa, com quem já tinha trabalhado em oficinas "menores" de confecção. Quando Inés me contou sobre a sua chegada à fábrica (e, em sentido mais amplo, sobre o seu trabalho fora de casa), explicou que não tinha chegado "por necessidade" e sim pelo desejo de "se tornar independente do seu marido", com quem morava e tinha migrado quando jovem da província de Jujuy, sua terra natal. Segundo relatou numa conversa que tivemos um tempo depois da ocupação, "os donos" sempre tinham sido muito atenciosos com ela e suas/seus companheiras/os. Ainda se lembrava do episódio em que adiantaram uma quinzena para pagar a viagem para o enterro da sua mãe, ou quando emprestaram a casa para o casamento de Daniel, um operário que trabalhava no seu setor. Esta lembrança aprofundava o contraste que lhe causara a resposta desrespeitosa de um deles na manhã do dia 18 de dezembro:

Nesse dia, tínhamos descido, um grupo do $5^{\circ}$, um grupo do $3^{\circ}$ e do $2^{\circ}$, e com eles estava a nossa delegada, a delegada do $2^{\circ}$ andar... E começamos a falar sobre por que pagavam assim, que o nosso dinheiro não dava... E numa dessas [nome de um dos donos], sai muito arrogante e diz: "O que vocês querem, que traga o dinheiro de fora?", e bateu a porta na nossa cara. Para mim, na verdade, foi a pior coisa que podia ter feito, viu? Porque uma pessoa com raiva pode te dizer muitas coisas, mas que você esteja na necessidade e ela te diga "o que você quer, que eu traga o dinheiro de fora?", cheio de ironia, foi a primeira vez que senti que me machucavam, como se tivessem me dado uma punhalada. Porque como é que você pode... Para mim foi uma coisa terrível essa, que tenham me falado isso, sei lá, tivessem dito "não, não tenho dinheiro", talvez tivesse me enganado nesse momento, qualquer coisa não teria me machucado tanto como machucou com essa soberba de dizer "o que você quer, que eu traga o dinheiro 
de fora?" e fechar a porta, foi e bateu com a porta na nossa cara. E isso foi o que para mim, para mim... Eu estava lá e foi o que me deu uma impressão horrível (Inés, 42 anos, há oito anos na empresa).

O relato de Inés mostra-se eloquente em diversos sentidos. Por um lado, seguindo a mesma linha das narrações anteriores, sua reconstrução se ancora em referências emotivas que incluem suas/seus companheiras/os. Referências que, como ela expressava, eram sentidas no corpo: "foi a primeira vez que senti que me machucavam, como se tivessem me dado uma punhalada". Neste ponto, talvez com maior ênfase que nos casos anteriores, a narrativa feita por Inés daquele momento recorre a uma série de imagens que se explicam a partir de sensações corporais, como a de se sentir ferida pela soberba. Por outro lado, situa as ações "dos donos" nesse mesmo registro. Ainda que fosse para ela intolerável, a resposta deles podia também ser lida a partir da raiva. Finalmente, a descrição da relação e os intercâmbios entre ambos, trabalhadoras/es e empresários, inscrevem-se no mesmo registro mediante imagens como o sarcasmo, a contrariedade ou a apatia.

Segundo o seu relato e o de outras/os companheiras/os, durante o resto da jornada de trabalho, voltaram aos seus postos esperando que "o dinheiro chegasse", algumas/alguns cumprindo a ordem de terminar a produção, outras/os iniciando uma medida de força que desembocaria na ocupação da fábrica. A convivência destas duas situações durante o resto da tarde aporta elementos para retomar as descrições que Beatriz, Margarita e Julia fizeram desse dia, em que práticas cotidianas de trabalho que se prolongaram em uma permanência impensada combinaram-se com a organização da ocupação. Por volta das 3 da tarde, horário habitual de saída, "os donos tinham ido embora". Foi então que um grupo, no qual estavam Julia e Pedro, começou a percorrer os andares propagando a ideia de permanecer. Algumas/alguns, com temor, preferiram voltar no dia seguinte. Outras/os, sem possibilidades de voltar para suas casas, passaram a noite pela primeira vez na fábrica. Julia rememorou assim:

Nós nos reunimos com o setor de passar roupa às 15 para as $3 \mathrm{~h}$, eu me lembro que eram 20 para as $3 \mathrm{~h}$. Porque às 15 para as $3 \mathrm{~h}$, algumas pessoas já iam tomar banho. Nós nos reunimos com eles e subimos com Roberto [nome de um colega daquele setor], que disse: "bom, companheiros", disse assim, não é? [com tom enérgico, como se o imitasse nesse momento], "viemos falar com vocês, estamos com os setores de calça e de engomadaria e achamos que vamos ficar. Mesmo que venham oferecer 20 pesos, nós vamos ficar do mesmo jeito, porque eles seguramente estão pensando em esvaziar a empresa quando a gente sair de 
férias, então a gente... Então a gente, quem quiser nos acompanhe, estamos no segundo andar, nos fundos, e esperamos por vocês lá; nós daqui não sairemos, quem quiser dedurar para os patrões" — isto ele disse pelos delegados de... "que vá dizer a eles". Aqui não tem sindicato nem ninguém que nos ajude, nós vamos ficar e sabemos nos defender, e que venham e se interem os patrões amanhã, que aqui não estamos dispostos nem a trabalhar, nem a mover um dedo, nem sequer a irmos embora se eles não trouxerem o nosso salário, salário a que temos direito" (Julia, 33 anos, há sete anos na empresa).

Este trecho da narrativa de Julia marca uma mudança de eixo em relação ao relato anterior, no qual se evocava a sensação de desespero que os tinha "juntado", aprofundando a ideia de organização. O relato descreve em que consistiu: comunicar a ideia aos demais setores, explicar os motivos da decisão, conseguir convencer as/os companheiras/os. Neste relato, começa a aparecer toda uma série de elementos que logo ganharam centralidade na construção das argumentações públicas que legitimaram a demanda: a ocupação é descrita como uma medida para exigir o pagamento dos vales atrasados, mas fundamentalmente para impedir o fechamento e o "esvaziamento" da fábrica. Não obstante, nesta descrição, as referências emotivas não estão ausentes. Em particular, a ideia de desamparo — "não há ninguém que nos ajude" - evoca a falta de apoio por parte das/os delegadas/os e, em sentido mais amplo, do sindicato, que no caso deste processo de recuperação adotou uma posição crítica a respeito das ações levadas adiante. ${ }^{17}$

Às 8 da noite as reivindicações tinham sido definidas, estabelecendose "cinco pontos". Roberto, um homem de 48 anos que trabalhava no setor de engomadaria, ainda guarda com ele a folha em que ficaram gravadas, escritas à mão, e que me mostrou na sua casa, enquanto narrava o início da ocupação. "Se você quiser, desliga o gravador que eu vou buscar", disse-me e, minutos depois, leu em voz alta, uma a uma, as reivindicações.

Aqui está. Os cinco pontos que nós levantamos para exigir dos empregadores. O primeiro ponto diz que a empresa não fizesse represálias contra os trabalhadores, nem demissões. Segundo ponto: reincorporação dos companheiros despedidos. Terceiro: que pagassem os salários atrasados naquela sexta-feira, no mínimo \$200. Quarto: refinanciamento da dívida que a empresa tem, ou que propusessem ao governo novos créditos. Olha o que a gente pedia! Quinto: manter a qualquer custo nossa fonte de trabalho. Estes são os cinco pontos que elaboramos naquele dia. A ideia era permanecer na fábrica até que os patrões viessem e solucionassem os problemas salariais. 
Na mesma hora, algumas pessoas que moravam na região, familiares das/dos trabalhadoras/es e companheiros de Julia, "junto aos quais tinha lutado pela sua moradia", vieram até a fábrica para lhes trazer comida. Na entrevista que fizemos quase dois anos depois na sua casa, ela lembrava disto assim:

Eram 9 horas da noite e chegaram meus vizinhos com comida. Nossa, uma alegria!, [...] meus vizinhos que tinham ficado ainda morando em La Rioja [faz referência às/aos suas/seus companheiras/os da organização pela moradia de que participara e graças à qual tinha conseguido a sua casa], que não tinham conseguido a moradia ainda porque tínhamos formado grupos, eles foram para lá com comida. Já era outro o porteiro, um velhinho mais sagaz, que nos chamou. Os outros chegaram com pizzas, bifes à milanesa. Olha, não sei, para mim, eu... os cumprimentava, tinha vontade de chorar, porque estava do lado de cá, como tinha batalhado pela moradia com eles, junto com eles, estava deste lado e eles do lado de fora e eu de dentro... "Do que você precisa? O que você quer?". Eu digo "Sprays de tinta, tragam para a gente sprays". Bem, não sei onde eles conseguiram, coitados, mas trouxeram sprays para mim, eles trouxeram, e nessa hora chega a esposa do Roberto, outra leva de comida. Você não imagina o banquete naquela noite! Depois, todos subimos, o irmão do Julio, me lembro, ou seja, não eram só meus vizinhos, mas também o irmão do Julio, também, que tinha chegado. Fomos todos. Elas contentes [referindo-se às suas companheiras de trabalho]: "Olha como os vizinhos vieram até nós, os vizinhos da Julia, mulher do Roberto. Olha! Como nunca! Há quanto tempo que não comíamos assim". Bom, depois as meninas começaram a chorar, não é? Dizendo como estava sua família e nós ali, comendo assim... E então os sprays, meninas, o que acham de fazermos cartazes? Elas não, uma sim, outra não... Vamos fazer cartazes, a gente faz cartazes dizendo, "[Nome do dono] paga os salários" para quando vier amanhã se arme, que se veja que isto é um escândalo, não? (Julia, 33 anos, há sete anos na empresa).

Com a mesma ênfase e partindo do mesmo registro que mobilizou para falar dos momentos anteriores, marcados pelo desespero, Julia narrou então as horas que se seguiram, em que essa sensação se entremeava com a alegria, ao mesmo tempo em que as primeiras reivindicações iam sendo escritas em papel. Uma alegria que a comovia ao se sentir acompanhada e que se estendia às suas companheiras. A narrativa enfatizava o contraste entre essa alegria, "o banquete naquela noite" e o sofrimento pelas suas famílias. Ao mesmo tempo, como pude encontrar em outros relatos, a alegria se vinculava ao fato de sentir o apoio das pessoas do bairro, de seus familiares e companheiros/as. 
No dia 19 de dezembro a recuperação tinha começado. Aqueles que no dia anterior tinham voltado para suas casas chegaram nesse dia às 6 da manhã - como de costume. Mas desta vez "os donos" já não estavam na fábrica. Encarregadas/os, quadros superiores, empregadas/os administrativas/os e de vendas permaneceram na rua. Somente as/os operárias/os se juntaram pouco a pouco. Na primeira assembleia definiram a formação de uma comissão interna, composta por seis delas/es. Esta seria a face visível da fábrica durante os próximos meses. Horas mais tarde, o presidente De la Rúa decretava o estado de sítio. Alguns deles lembram a sensação de temor diante desta medida desobedecida, em função da qual aconteceram os panelaços, os saques e as mobilizações em diferentes pontos do país. As referências a esse momento transmitem a incerteza em relação ao que viria e o medo da repressão policial, sensações que se amalgamavam com a comoção de um país mobilizado:

No dia seguinte, Cavallo renunciou e foi decretado o estado de sítio, e nós com a fábrica ocupada! "Não!", dizíamos, "Vai vir a polícia e vão nos tirar. O que fazemos?"... Alguns queriam fugir, diziam: "Não, vamos embora". Tiramos as bandeiras, fechamos as janelas e ficamos no fundo, enquanto víamos na televisão o que estava acontecendo, os saques... ou seja, a rebelião do povo, do jeito que saía às ruas para brigar. As assembleias, os estudantes, gente humilde, de classe média, todos saíam à rua, era um rebuliço total. Era uma coisa terrível para nós. Assim passamos uns dias, até que... O Natal nós passamos aqui dentro, Ano Novo passamos aqui. Um grupo ficou para o Natal e o outro ficou para o Ano Novo. Assim fomos, como se diz, fazendo rodízio entre os grupos. Eu, por exemplo, na primeira instância tinha ficado os três dias, depois um dia fui para casa, voltei, outros três dias, assim fomos, até que vimos a necessidade de nos organizarmos um pouco melhor. Não podíamos ficar todos aqui. Então fomos nos revezando e, bom, os donos não apareciam nem nada, né? Tinham desaparecido completamente (Pedro, 41 anos, há sete anos na empresa).

O relato de Pedro, esse operário de origem boliviana que tinha sido eleito delegado poucos meses antes da ocupação, é parte de uma conversa que mantive com ele em agosto de 2002, quando a fábrica já tinha se convertido num caso emblemático das empresas recuperadas. Nesse momento, as/os operárias/os tinham se vinculado às assembleias de bairro — formadas a partir das "jornadas de 19 e 20" — aos partidos políticos de esquerda e a outras empresas recuperadas, em particular um conjunto de experiências estimuladas por sindicatos que promoviam formas de "democracia operária" e "controle operário" da produção. A reconstrução dessa noite feita por Pe- 
dro recupera as interpretações que se fizeram a partir dessas organizações em relação aos acontecimentos, expressos em ideias, como a "rebelião do povo", ao mesmo tempo em que transmite a atmosfera daquele momento, assim como Julia, num relato que combina sensações de temor e euforia, destacando em seguida a necessidade de se organizar. Nesse sentido, a própria ideia de organização de que fala Pedro e a forma que foi tomando devem ser compreendidas no contexto dessas relações com organizações sociais e políticas.

Uma das primeiras ações realizadas no início da recuperação foi a implementação de uma vigilância rotativa na qual as/os trabalhadoras/es passavam a noite na fábrica. Para garanti-las foram formados grupos estáveis de seis trabalhadoras/es, que se alternavam a cada oito dias. A vigilância começava uma vez encerradas as tarefas de confecção, neste caso, às 3 da tarde, e se prolongava até as 6 da manhã do dia seguinte, momento em que eram retomadas as tarefas de produção. Nas primeiras horas asseguravam o controle da entrada e saída da fábrica, permanecendo na entrada do prédio. Isto incluía a recepção das pessoas que se aproximavam do lugar, entre as quais vizinhas/os do bairro, militantes de diferentes organizações, jornalistas de diversos meios de comunicação, estudantes universitários e, inclusive, funcionários públicos. Na maioria dos casos, a recepção das visitas implicava o relato da recuperação e a atualização da situação legal ou financeira; a coordenação de ações de protesto e articulações com as diferentes organizações; e as instâncias de negociação com agentes governamentais. Estes relatos ressaltavam e definiam uma série de eventos que se apresentavam como marcos fundadores da ocupação e do início da recuperação. Entre eles, destacava-se o processo de "esvaziamento", descrevendo as manobras fraudulentas dos empresários e a retirada de pertences nos últimos dias, a deterioração da relação tanto pessoal como laboral com os trabalhadores, o aumento das dívidas salariais e, principalmente, o abandono da fábrica. Essa descrição incluía tanto uma forma de reconstruir a história como uma maneira de contá-la, em que se destacavam a experiência de sofrimento e a situação de injustiça.

As vigilâncias incluíram as noites de Natal e Ano Novo, às quais Pedro fez referência. Não seria a única ocasião em que passariam "as festas" na fábrica. Foram numerosas as vezes em que, mais adiante, relatariam esses dias nas entrevistas ou em conversas informais que mantivemos na fábrica. Às vezes comovidos em função do que foram capazes de fazer, outras evocando a tristeza de um Ano Novo "com o pouco que tinha para comer". Os dias subsequentes foram também descritos como momentos de sofrimento e humilhação, sobretudo quando tinham de "sair para pedir", uma situação 
que, afirmavam, nunca teriam acreditado que um dia enfrentariam. É assim que se lembra María, uma trabalhadora de 72 anos, incorporada à fábrica como aposentada: ${ }^{18}$

M: Eu me lembro do Natal, um Natal mais triste, lá dentro, cuidando da fábrica... Mas todos os vizinhos que passavam traziam comida, deixavam para nós no carrinho. ${ }^{19}$

MI: Um carrinho?

M: Um carrinho para que nos dessem as doações. Depois eu pedia de um lado da vereda e Diego [faz referência a um colega da fábrica] pedia do outro lado, e tínhamos os clientes que já nos davam as moedinhas pela manhã, e com essas moedinhas fazíamos a comida ao meio-dia. E com o que sobrava, se alguma companheira queria ir embora, viajava com essas moedas. Então para nós foi muito... Na verdade nós lutamos tanto, tanto, para ter o emprego. Porque a única coisa que a gente queria era o trabalho (María, 72 anos, há sete anos na empresa).

No começo de janeiro, a necessidade de organização exigiu não apenas manter as vigilâncias, mas também a realização de ações de protesto, que nos primeiros tempos foram sobretudo piquetes na rua e mobilizações, logo se somando a decisão, também mediada pelo medo, de reiniciar a produção "em suas mãos". Assim, a partir do dia 18 de dezembro, as práticas cotidianas dessas/es trabalhadoras/es, não incluíram unicamente o desenvolvimento de "atividades produtivas", mas estas se entremeavam com "ações de protesto". Ou, mais precisamente, a própria produção transformou-se numa ação de protesto (Fernandez Alvarez 2006). Nesse caminho, em fins de janeiro, a demanda pela "fonte de trabalho" 20 tinha ficado colocada, como se expressa no trecho do comunicado de imprensa que transcrevo a seguir:

Nós, os trabalhadores de [La Celeste], não aceitamos mais a chantagem do sistema, nem tampouco da empresa. Não queremos perder o trabalho que mantém nossas 120 famílias, rejeitamos o pagamento como salário de $\$ 5$ - porque o consideramos indigno como trabalhadores e como pessoas, queremos todo o nosso salário de há dois meses, o bônus e as férias. O senhor [nome de um dos proprietários da firma] fugiu da fábrica, deixando as máquinas e os bens produzidos, sem pagar nenhuma de suas dívidas. Portanto, tomamos a decisão histórica de ocupar a empresa pacificamente, para evitar que levem embora o estoque e as máquinas, em defesa única e exclusivamente de nossa fonte de trabalho, até as últimas consequências. Agora [nós], os trabalhadores, devemos decidir como garantir nosso trabalho e nosso futuro. O caminho que já iniciamos é o da luta. Chamamos todos os trabalhadores a nos apoiarem. 
Distribuído poucas semanas depois do dia 18 de dezembro, este trecho do comunicado de imprensa condensa os principais argumentos em cuja base esta demanda se legitimou. Como analisamos em trabalhos anteriores (Fernández Álvarez 2006), seu eixo estava na dignidade do trabalho em face da indignidade do desemprego. Na necessidade de garantir a continuidade da fonte de trabalho como único meio para consegui-lo. Na capacidade e na vontade dos trabalhadores, enquanto sujeitos dignos, de levarem adiante a produção. No sofrimento das/os trabalhadoras/es e suas famílias. Neste sentido, os argumentos públicos, expressos a partir da lógica da legitimidade, mostraram também o desdobramento de emoções e sentimentos, como o desamparo, a indignação ou a raiva. Emoções que se mostraram publicamente não apenas nos discursos, mas também nas mobilizações, em piquetes de rua e maquinaços, ${ }^{21}$ ações de protesto nas quais a fábrica foi defendida com o corpo.

Esta entrada em jogo de sentimentos e emoções se fez presente em diferentes âmbitos, como conferências de imprensa, diante de situações de despejos. Neste caso, os operários e as operárias, principalmente as mulheres, eram colocados em frente às câmeras acompanhadas de suas/seus filhas/os, afirmando a decisão de "defenderem como leoas o posto de trabalho e a comida de cada dia de nossos filhos", uma ideia que se realçava em expressões como a defesa da fonte de trabalho "com unhas e dentes" diante do "sabor amargo do desemprego".

O mesmo registro foi o que escutei nas intervenções públicas, em encontros ou reuniões com outras recuperadas. Nesses eventos, uma parte central do cronograma era constituída pela apresentação de cada uma das fábricas ou empresas convocadas. Para isso, as trabalhadoras e os trabalhadores eram convidados a relatar a sua história e trasmitir a sua experiência a colegas que tinham passado por situações similares ou estavam iniciando processos semelhantes. Nessas narrações, a exposição de sentimentos e as referências emotivas adquiriam especial centralidade. Em muitos casos, com os olhos cheios de lágrimas ou a voz embargada, lembravam os primeiros tempos, relatando situações de penúria, falta de alimento ou desamparo, as noites em claro e as situações de repressão. Momentos críticos de angústia, temor, incerteza e sofrimento que tinham marcado os começos e se contrapunham a sensações de alegria, orgulho ou entusiasmo diante de situações de "conquista".

Nessas cenas expunha-se e compartilhava-se o medo em face da experiência do eminente fechamento, a angústia diante da possibilidade de ficar sem emprego, o sofrimento para sustentar a luta, o temor à repressão e o orgulho de manter a fonte de trabalho apesar de tudo. Essa expressão 
obrigatória dos sentimentos (Mauss 1979) fez parte de um processo de construção política que privilegiou a apresentação de certas emoções ou sentimentos (como o sofrimento, a raiva ou o temor). Uma entrada em cena das emoções que permitiu conseguir adesão na medida em que resultou num registro que, ao se opor ao distanciamento, apelou para o compromisso (Pita 2010), ${ }^{22}$ promovendo formas de legitimidade (Barreira 2001).

\section{Conclusão: a política das emoções}

As recuperações de fábricas, assim como outras formas de mobilização e protesto desenvolvidas nos últimos anos na Argentina, chamaram a atenção das/dos cientistas sociais porque permitiram pôr em xeque alguns pressupostos naturalizados no âmbito acadêmico local, como as ideias de descoletivização e apatia política. Na abordagem desses processos, as teorias da ação coletiva, nas suas diferentes vertentes, ganharam peso significativo. Esses marcos analíticos focalizam os momentos extraordinários, como as expressões públicas do protesto, ou a mobilização social, desenvolvendo um olhar estratégico da ação que em alguns casos se explica por fatores relativos a mudanças no contexto político, ou então pela influência de elementos culturais, em algumas suposições mediadas pelas emoções. Em todos os casos, isto presume pensar esses processos como resultantes das motivações (individuais) de pessoas que decidiram (racionalmente) envolver-se em ações coletivas.

A meu ver, um dos principais problemas dessa análise reside em considerar que as ações que as pessoas realizam respondem definitivamente a uma motivação que deve ser, portanto, estratégica e racional. Por esse caminho, as práticas se desvinculam da experiência, da maneira como vamos tecendo, na nossa vida cotidiana, relações que tornam possível desenvolver ações conjuntas, para além da nossa intencionalidade. E mais: o foco nas motivações supõe, em alguma medida, que o desenvolvimento de uma ação conjunta, neste caso a ocupação da fábrica, seja produto de uma soma de vontades - valendo a insistência de caráter racional - que se somam em prol de um objetivo comum, neste caso a defesa da fonte de trabalho. O que o meu trabalho tentou mostrar é como neste fazer juntas/os, de maneira (im)pensada, as operárias e os operários da fábrica agruparam suas experiências cotidianas de frustração, angústia e sofrimento a partir da reunião de emoções e sensações compartilhadas, como o medo de perder o trabalho, o desespero diante da possibilidade de fechamento da empresa, a raiva pelos salários devidos ou as respostas desrespeitosas dos donos. 
Entendo que aqui reside um dos primeiros sentidos a que me refiro quando sustento que as emoções podem ser pensadas também como práticas políticas, capazes de estabelecer um modo de comunicação, ao mesmo tempo verbal e não-verbal, que põe em jogo um registro íntimo, no qual intervêm relações afetivas e experiências próximas.

Neste ponto a antropologia tem desenvolvido uma perspectiva que focaliza as práticas cotidianas, pondera uma análise do ordinário e privilegia um olhar sobre as pessoas e suas experiências de vida. A partir deste nível de análise, o registro das emoções ganha destaque não como um elemento ou fator que permite explicar disposições à ação, mas como um registro que se estende na vida cotidiana e diz respeito ao modo como estabelecem-se relações, compartilham-se experiências e constroem-se ações comuns. Nessa cotidianidade, as ações não constituem atos estratégicos ou calculados. Revelam-se, a um só tempo, organizadas e impensadas. Trata-se de uma comunicação que se transmite através de palavras, mas também de formas não verbalizadas, como o pranto, o riso, um olhar ou um abraço. Um código não verbal, traduzido nas narrativas em termos como desespero, medo, raiva ou alegria.

Indo mais longe, reler os dados por esta chave deu relevância ao peso que este registro ganhou não apenas na partilha da experiência, mas também no processo de construção política. Tanto no plano das relações íntimas como no da legitimação das demandas. Neste segundo plano, o registro emotivo atualizou-se nos discursos e nas práticas de que as trabalhadoras e os trabalhadores lançaram mão para conseguir recuperar a sua fábrica. Entendo que aqui reside o segundo sentido a que recorro quando afirmo o caráter político das emoções, desenvolvendo o que alguns autores chamam de "solidariedade afetiva" (Juris 2008). Neste caso, a expressão pública de emoções e sentimentos se fez central para conseguir o apoio dos "vizinhos", convencer os "políticos", obter adesões de grupos sociais, captar a atenção da mídia e atrair o olhar de intelectuais e acadêmicos. Como Julia conseguiu fazer comigo em abril de 2002, numa sala de aula da Faculdade de Filosofia e Letras.

Com base nesta primera adesão, foi-me possível levar adiante o trabalho de campo que, depois de quatro anos, permitiu que eu obtivesse o título de Doutora e logo ingressar na carreira de pesquisadora do CONICET. Nesse estar lá, Julia e seus/suas companheiros/as converteram-se em pessoas de carne e osso com as quais pude entabular relações mais íntimas, acompanhando-os/as na "sua luta pela fonte de trabalho". Assim, foi possível compartilhar espaços variados como mobilizações, acampamentos, despejos ou situações de repressão, nos quais experimentei com elas/es momentos de celebração e tensão, alegria e frustração. Emoções e sentimentos que, quem sabe, estejam na base da redação deste artigo. 
Recebido em 11 de junho de 2009

Aprovado em 30 de janeiro de 2011

Tradução de Fernanda Guimarães

María Inés Fernández Álvarez é pesquisadora do CONICET. E-mail: < mifernandezalvarez@gmail.com>

\section{Notas}

' Uma versão prévia deste trabalho foi apresentada nas V Jornadas de Investigación en Antropología Social (2008). Agradeço as leituras (releituras) e sugestões de Sebastián Carenzo, os comentários à primeira versão de Mabel Grimberg, Virginia Manzano e Florencia Partenio, e as substantivas contribuições das/dos avaliadoras/es anônimas/os do artigo.

${ }^{1}$ Os nomes das pessoas e da fábrica foram modificados. Adoto itálico para termos nativos, aspas duplas para citações ou referências textuais e aspas simples para relativizar ou destacar termos.

${ }^{2}$ Esta medida, anunciada em 2 de dezembro de 2001 e sancionada como Decreto (1570), dispunha sobre a restrição à retirada de dinheiro em espécie de fundos a prazos fixos, contas correntes e poupanças, bem como transferências para o exterior. O Decreto tinha como principal objetivo evitar a fuga de depósitos e a especulação sobre uma possível saída da conversibilidade (que estabelecia a paridade dólar-peso), vigente desde 1991. Cabe apontar que esta medida era tomada no âmbito de uma profunda recessão econômica, que vinha se aprofundando desde meados dos anos 90, expressa em indicadores, como elevados níveis de desemprego, que chegaram em outubro de 2001 a $18,3 \%$.

${ }^{3}$ Entre o momento da sua renúncia e janeiro de 2002 sucederam-se quatro presidentes, sendo finalmente designado interinamente Eduardo Duhalde, que promulgou a Lei de Emergência Pública e de Reforma do Regime Cambial que pôs fim à conversibilidade.

${ }^{4}$ Com esta denominação se fez referência a uma forma específica de reivindicação pela "fonte de trabalho", que incluiu a ocupação do imóvel, a gestão coletiva da produção, o desenvolvimento de negociações com diferentes agências do Estado para conseguir a continuidade da unidade produtiva e a formação de uma cooperativa de trabalho. Como desenvolvi em trabalhos anteriores (Fernández Álvarez 2007), apesar de as empresas recuperadas terem se multiplicado e obtido notória visibilidade a partir 
dos acontecimentos de dezembro de 2001, esses processos vinham se desenvolvendo desde meados dos anos 90, encontrando-se antecedentes diretos na década de 1980.

${ }^{5}$ A presença diária de estudantes, jornalistas, intelectuais ou militantes marcou o ritmo do meu trabalho de campo durante os primeiros meses. Em função disso, procurei diferenciar a minha prática, que se propunha como uma tarefa de longo prazo, da presença desses 'outros' que também eram meus interlocutores no campo. Estar, permanecer, transformar minha presença em algo cotidiano eram características que permitiam diferenciar-me dessas/es outras/os, possibilitando um diálogo orientado mais para a reconstrução da experiência do que para o relato "oficial". Apresentar o projeto de pesquisa, explicar o porquê da minha escolha, descrever o fazer antropológico e discutir os termos da minha estada foram alguns dos requisitos necessários para desenvolver essa tarefa. Uma das primeiras questões foi apresentar, diante de uma assembleia, em que consistia o trabalho e deixar uma cópia do projeto de pesquisa. Esta instância, da qual dependeu a possibilidade de levar adiante o meu estudo, constituiu para mim um verdadeiro 'rito de passagem'. De forma muito sintética, tentei traduzir em linguagem coloquial o conteúdo do meu projeto de doutorado, naquele momento extremamente carregado de preocupações teóricas e afastado da cotidianidade de uma recuperada. Pouco tempo depois pude circular livremente pelos andares da fábrica, pelos quais se distribuíam os setores da produção, assim como observar o processo de trabalho. A possibilidade de ingressar no "horário de trabalho" mostrou-se fundamental não apenas em função de registrar o processo produtivo, mas também para estabelecer um vínculo mais pessoal com as/os trabalhadoras/es.

${ }^{6}$ Neste relato explicava-se que, a partir de 1998, os donos tinham suspendido os aportes à previdência social e, desde 2000, tinham interrompido o pagamento do salário quinzenal, substituído por um vale semanal que consistia em um recebimento adiantado da quinzena. O montante desse recebimento foi decaindo ao longo de 2001 até chegar, na última semana, ao valor de 5 pesos.

${ }^{7}$ Essa categoria faz referência às práticas ilegais que se desenvolvem diante de situações de falência em que os empresários retiram do estabelecimento maquinário ou insumos da produção com o objetivo de que não sejam incluídos no leilão.

${ }^{8}$ Mecanismo de negociação de dívidas com diversos credores que pode evitar a falência de uma empresa em crise.

${ }^{9}$ As teorias do comportamento coletivo consideravam as emoções como porta de entrada para entender toda a ação política que se desse fora das instituições. Nesse contexto, as multidões e suas dinâmicas foram concebidas como coração do protesto e os comportamentos coletivos se explicaram como produto da anomia, da irracionalidade das massas e do desencadear de mecanismos de manipulação que arrastavam os indivíduos à ação por efeito de contágio ou patologias. A aproximação dos cientistas sociais como ativistas ou simpatizantes dos movimentos que estudavam, a partir dos anos 1970, estimulou uma revisão dessas explicações, reorientando a perspectiva para olhares estruturais, racionalistas e organizados da ação coletiva. Em contraposição, os 
atores do protesto foram considerados grupos que perseguiam interesses individuais e os movimentos foram vistos como uma extensão normal da vida social, uma forma de fazer política de outra maneira. As emoções ficaram, assim, à sombra.

${ }^{10}$ Como desenvolvi em trabalhos anteriores (Fernández Álvarez 2006), as teorias da ação coletiva em suas diferentes vertentes partem de um pressuposto compartilhado segundo o qual a ação coletiva é o resultado do envolvimento (individual) das pessoas numa ação comum - um ator racional que se move em prol de um interesse estratégico a partir de um cálculo custo-benefício. A partir deste princípio, procurase identificar fatores que expliquem as motivações das pessoas para se envolverem em ações coletivas, ponderando as dimensões de caráter estratégico ou as variáveis identitárias, culturais e emocionais.

${ }^{11}$ Segundo estas/es autoras/es, as emoções definiram uma categoria ideológica cujo papel foi central no pensamento acadêmico ocidental, a partir das quais se sustentam dicotomias como mente/corpo, comportamento/intenção, indivíduo/sociedade, consciência/inconsciência (Lutz 1986; Lutz \& White 1986). Em função de rever esta tradição, consideraram as emoções como pensamentos corporificados (Rosaldo 1984), uma linguagem social que se expressa no corpo (Abu-Lughod \& Lutz 1990).

${ }^{12} \mathrm{O}$ trabalho de campo estendeu-se de abril de 2002 a março de 2005, compreendendo dois níveis de indagação articulados. Um nível intermediário de análise, de caráter setorial, no qual levei em conta o processo de recuperação de empresas na cidade de Buenos Aires, permitiu-me observar diferentes casos, realizando entrevistas em profundidade com trabalhadoras/es de diferentes recuperadas, dirigentes das organizações que as iniciaram e funcionárias/os de diversas organizações públicas vinculadas ao setor. Um nível em profundidade, no qual desenvolvi a maior parte do meu trabalho de campo, seguindo o caso de uma fábrica de confecção. Este artigo analisa este caso a partir de um trabalho de releitura dos dados, retomando e aprofundando reflexões da conclusão de minha tese de doutorado.

${ }^{13}$ Embora minha chegada ao campo seja posterior aos primeiros momentos que reconstruo neste artigo, a análise está principalmente centrada no relato das trabalhadoras e dos trabalhadores. Retomo, para isso, tanto parte das entrevistas realizadas ao longo da minha pesquisa como um relato de caráter mais fragmentário, que pude escutar durante conversas informais em situações diversas como almoços, passeatas, esperas nos escritórios de funcionários do Estado, "tempos mortos" em encontros de fábricas ou outras atividades públicas etc.

${ }^{14}$ Na Argentina, o seguro-desemprego foi implementado em 1991, no âmbito de uma série de reformas introduzidas na legislação trabalhista. Esta regulamentação estabelece que os beneficiários do seguro são aqueles que possam demonstrar ter tido uma relação de trabalho com certa permanência no tempo e comprovar, mediante documento legal, a situação de desemprego (demissão sem justa causa, ou por falência, ou concurso preventivo do empregador). A duração do subsídio de desemprego se dá em relação ao tempo efetivamente trabalhado e pago à Previdência Social, sendo a duração do benefício de no mínimo quatro e no máximo 12 meses. 
${ }^{15}$ No ano 2000 foi decretada a falência da empresa. Nesse momento a firma mudou de nome e conseguiu converter essa situação jurídica numa instância prévia, sob a figura de "concurso preventivo de credores", na qual se encontrava no início da recuperação. A falência da nova firma foi decretada posteriormente ao início da recuperação, em outubro de 2003.

${ }^{16}$ As vigilâncias eram organizadas desde o momento da ocupação para garantir a custódia da fábrica.

${ }^{17}$ Foram reiteradas nos diferentes relatos as referências não apenas à falta de apoio, mas também ao comportamento "negociador" do sindicato, expressas na ideia de "traição dos dirigentes" que, ao invés de defenderem seu trabalho, "chegavam à fábrica, discutiam um pouco, levavam umas roupas e tudo continuava igual". A falta de apoio do sindicato das indústrias de confecção, ao qual pertenciam as/os trabalhadoras/es desta fábrica, não supõe, no entanto, que diferentes tradições políticas e sindicais tenham tido força no desenvolvimento das empresas recuperadas (Perelman \& Dávalos 2003; Fernández Álvarez 2006, 2007; Aizinczon 2009). Diferentemente deste caso, em outras recuperações o sindicato, ou mais precisamente algumas seccionais proporcionaram apoios substantivos ou agentes promotores das ocupações. O caso mais significativo foi talvez o da seccional Quilmes da Unión Obrera Metalúrgica (União Operária Metalúrgica) que desde a década de 1980 vem estimulando processos de ocupação e formação de cooperativas de trabalho como estratégia sindical diante de falências ou fechamentos de fábricas. Mesmo assim, a Federação Gráfica Bonaerense apoiou processos de recuperação, principalmente na cidade de Buenos Aires, formando uma Rede de Cooperativas Gráficas em 2006. Estas organizações sindicais promoveram alguns casos recentes, iniciados em fins de 2008, que continuaram se multiplicando ao longo de 2009 e 2010. Outros exemplos são o do Sindicato de Operários e Empregados Ceramistas de Neuquén, que impulsionou a ocupação e a gestão operária de uma das maiores empresas recuperadas, localizada no sul do país, ou o do Sindicato de Empregados de Comércio de Rosário. As experiências promovidas por essas organizações sindicais tiveram uma importante vinculação com o caso que analisamos durante 2002 e 2003.

${ }^{18}$ Ao longo dos anos 1990, a contratação de trabalhadores aposentados que se empregavam "en negro", ou seja, sem registro formal, foi uma prática frequente que tendeu a reduzir "encargos trabalhistas". Na sua maioria eram incorporadas pessoas, neste caso mulheres, que tinham sido empregadas previamente em relação de dependência com a firma.

${ }^{19}$ No original, changuito, que nesta acepção se refere a um carrinho de supermercado.

${ }^{20}$ Cabe destacar que, para além das diferenças de percursos, metodologias e posicionamentos político-ideológicos adotados, esta demanda articulou o conjunto das recuperações. 
${ }^{21}$ Estas ações, desenvolvidas durante o momento em que as/os trabalhadoras/es foram despejadas/os da fábrica, entre abril de 2003 e janeiro de 2004, consistiam na ocupação da via pública, instalando máquinas de costura de uso familiar, durante as quais as/os trabalhadoras/es, principalmente as mulheres, punham-se a costurar durante o lapso de algumas horas, vestidas com seus guarda-pós azul-claros.

${ }^{22}$ Em seu trabalho sobre as demandas por justiça de familiares de vítimas da violência familiar na Argentina, M. Pita (2010) recupera as reflexões de C. Lutz (1986) a respeito do estudo das emoções nas ciências sociais para mostrar o modo como esse registro incidiu no processo de politização das mortes por parte dos familiares. Seguindo Lutz, a autora chama a atenção para o paradoxo que envolve o olhar dicotômico sobre as emoções que, ao opô-las ao distanciamento, situa-as ao lado do compromisso. Assim, em sentido positivo, a emoção pode ser vista como provedora de um poder pessoal que intervém na construção de poder social e permite obter adesão

\section{Referências bibliográficas}

AIZINCZON, Fernando. 2009. Zanon. Una experiencia de lucha obrera. Buenos Aires: Ediciones Herramienta.

ABU-LUGHOD, Lila. 1985. "Honor and sentiment of loss in Bedouin Society". American Ethnologist, XII(2):245261.

. \& LUTZ, Catherine. 1990. "Introduction: emotion, discourse, and the politics of everyday life". In: __. (eds.), Language and the politics of emotion. Cambridge: Cambridge University Press - Maison de Sciences de l'Homme. pp. 1-24.

BARREIRA, Iryls. 2001. "Política, memória e espaço público: a via dos sentimentos". Revista Brasileira de Ciencias Sociales, XVI(46):97-117.

CALHOUN, Craig. 2001. "Putting emotions in their place". In: J. Goodwin, J. Jasper, M. and F. Polletta (orgs.), Passionate politics. Emotions and social movements. Chicago: The University of Chicago Press. pp. 45-57.
CSORDAS, Thomas. 1994. Embodiment and experience. The existencial ground of culture and self. Cambridge: Cambridge University Press.

FERNÁNDEZ ÁLVAREZ, María Inés. 2006. De la supervivencia a la dignidad. Una etnografía de los procesos de "recuperación" de fábricas de la Ciudad de Buenos Aires. Tesis de doctorado, UBA-EHESS.

2007. "De la recuperación como acción a la recuperación como proceso: prácticas de movilización social e acciones estatales en torno a las recuperaciones de fábricas". Revista Cuadernos de Antropología Social, XXV:89-110.

GOODWIN, Jeff; JASPER, James \& POLLETTA, Francesca (orgs.). 2001. Passionate politics. Emotions and social movements. Chicago: The University of Chicago Press.

JASPER, James \& GOODWIN, Jeff. 2006. "Emotions and social movements". In: 
J. E. Stets \& J. H. Turner (eds.), Handbook of the sociology of emotions. New York: Springer. pp. 611-635.

JURIS, Jeffrey. 2008. "Performing politics. Image, embodiment, and affective solidarity during anti-corporate globalization protests". Ethnography, 9(1):61-97.

LUTZ, Catherine. 1986. "Emotion, thought and estrangement: emotion as cultural category". Cultural Anthropology, I(3):287-309.

. \& WHITE, Geoffrey. 1986. "The anthropology of emotions". Annual Review of Anthropology, XV:405-436.

LYON, Margot. 1995. "Missing emotion: the limitation of cultural constructionism in the study of emotion". Cutural Anthropology, X(2):244263.

MAUSS, Marcel. 1979. "A expressão obrigatória de sentimentos". In: R. Cardoso Oliveira (org.), Mauss. São Paulo: Ática. pp. 147-153.

PERELMAN, Laura \& DÁVOLOS, Patricia. 2003. "Empresas recuperadas e trayectoria sindical: la experiencia de la UOM Quilmes". In: Gabriel Fajn (comp.), Fábricas e empresas recuperadas. Protesta social, autogestión e rupturas en la subjetividad. Buenos Aires: Centro Cultural de la Cooperación. pp. 185-222.

PITA, María Victoria. 2010. Formas de morir y formas de vivir. El activismo contra la violencia policial. Buenos Aires: Ediciones del Puerto - Centro de Estudios Legales e Sociales.

POLLETTA, Francesca. 1998. "'It was like a fever...'. Narrative and identity in social protest". Social Problems, XVV(2):137-159.

REEDY, William. 1997. "Against constructivism: the historical ethnography of emotions". Current Anthropology, 38(3):327-351.
ROSALDO, M. 1984. "Toward an anthropology of self and feeling". In: R. Shweder \& R. LeVine (eds.), Culture theory. Essays on mind, self and emotion. Cambridge: Cambridge University Press. pp. 137-157.

WORSLEY, Peter. 1980. Al son de la trompeta final: estudios de cultos "cargo" en Melanesia. Madrid: Siglo XXI. 


\section{Resumo}

Nos anos recentes, as emoções chamaram a atenção das pesquisas sobre ação coletiva. A partir de uma concepção racional desta última, foi desenvolvida uma visão cognitiva da emoção — baseada em uma tradição ocidental que opõe racional a irracional, mente a corpo, privado a público - segundo a qual as emoções seriam fatores motivacionais.

Neste artigo, elaboro uma revisão de parte de meu estudo etnográfico sobre fábricas recuperadas em Buenos Aires para analisar as emoções como práticas políticas. Proponho deslocar o debate sobre a irracionalidade/ racionalidade da ação e introduzir uma compreensão das práticas políticas como experiência encarnada. Com este objetivo, analiso a descrição que as/os trabalhadores/trabalhadores fizeram do momento da ocupação. Esta reconstrução demonstra a importância das emoções para articular a experiência e definir as reivindicações. O processo de construção de demandas implicou uma objetivação desta experiência e, ao mesmo tempo, de exposição pública de certas emoções e sentimentos.

Palavras-chave Emoções, Práticas Políticas, Racionalidade, Empresas Recuperadas, Cidade de Buenos Aires

\section{Abstract}

Emotions have achieved a certain prominence in recent studies of collective action. Based on a rationalist conception of the latter, many of the authors concerned have developed a cognitive view of emotion adhering to a western tradition of thought that divorces the rational from the irrational, mind from body and private from public. Emotions thereby become factors capable of explaining people's motivations in collective actions. In this article I review part of my ethnographic study of recovered factories in Buenos Aires in order to analyze emotions as political practices. I suggest shifting the debate away from irrational/rational action and towards an understanding of political practices as embodied experience. This aim in mind I analyze the workers' descriptions of the moment of occupation. This reconstruction shows us the importance of emotion in articulating the experience and in pursuing their claims. At the same time, the public display of feeling enables the workers to legitimate their demands and garner political support.

Key words: Emotions, Political Practices, Rationality, Recovered Factories, Buenos Aires 